\title{
Effects of turbulence on bacterial growth mediated through food web interactions
}

\author{
Francesc Peters*, Cèlia Marrasé, Josep M. Gasol, M. Montserrat Sala, Laura Arin \\ Institut de Ciències del Mar (CSIC), Pg. Joan de Borbó s/n, E-08039 Barcelona, Catalunya, Spain
}

\begin{abstract}
We performed laboratory experiments with natural seawater communities of the Northwestern Mediterranean to test whether turbulence could affect bacterial abundance and activity. There was no direct effect of turbulence on bacteria when they were uncoupled from the remainder of the microbial community. In the presence of the microbial community, bacteria showed higher activity and maintained high abundances for a longer time under turbulence than in still water Thus, turbulence sufficiently altered some microbial component or process in the water samples that indirectly affected bacteria. The population dynamics of bacteria and pigmented eukaryotes suggests that, under turbulence, there is a community grazing shift from smaller to larger prey sizes. This shift can be explained in terms of the advantage to protozoan predators which are able to prey on larger and more nutritious cells when the encounter rates with these cells are increased through the shear present under turbulence. The result is a higher control on phytoplankton and a relaxation of grazing on bacteria. Hence, episodic high turbulence events in coastal systems could accelerate nutrient recycling.
\end{abstract}

KEY WORDS: Bacteria - Turbulence - BacteriaLactivity - Phototrophic pico- and nanoplankton . Grazing Shift of preferred prey size

\section{INTRODUCTION}

Experimental evidence of the effects of turbulence on substrate uptake by bacteria is meager and contradictory. Fluid motion has been shown to increase uptake rates of low (Logan \& Kirchman 1991) and high (Confer \& Logan 1991) molecular weight substrates by bacteria. In another study, Moeseneder \& Herndl (1995), measured bacterial production under turbulence and found mostly a detrimental effect unless the sample had been pre-exposed to turbulence. However, when only bacteria were present in the experiments, no effect was observed. Moreover, Confer \& Logan (1991) and Moeseneder \& Herndl (1995) tested levels of turbulence 3 to 4 orders of magnitude higher than those that can be found in the ocean under stormy conditions.

Bacteria require a supply of dissolved substances to grow. These substances include inorganic salts, metals and dissolved organic matter containing mainly carbon but also organic nitrogen and phosphorus. In most

\footnotetext{
·E-mail: cesc@icm.csic.es
}

parts of the ocean, the rate of supply of solutes to the cell surface, which depends, among other parameters, on the ambient solute concentration, is lower than the uptake rate of these substances by the cell (Jumars et al. 1993). By raising the ambient solute concentration, the gradient of solute to the cell surface is increased, consequently increasing the flux of solutes to the cell surface. Thus, ennchment experiments, where 1 or more nutrients are added to seawater, result almost unequivocally in higher bacterial growth (Wheeler \& Kirchman 1986, Kirchman et al. 1991, Pomeroy et al. 1995, and many others). Fluid motion relative to organisms can replace nutrient-depleted water around cells with ambient nutrient concentration water. In that sense, swimming and sinking may help some osmotrophs maintain a flux of nutrients towards the cell (Kiørboe 1993). Turbulence and the shear derived from it can also increase the relative motion of fluid with respect to cells.

For bacteria, all theoretical calculations show that the increase of nutrient flux through turbulence is too small to be of any significance. For example, for a $1 \mu \mathrm{m}$ bacterium swimming at 50 body lengths $\mathrm{s}^{-1}$ under a 
fairly high turbulent dissipation rate $\left(\varepsilon=10^{-2} \mathrm{~cm}^{2} \mathrm{~s}^{-3}\right)$, the nutrient flux increase owing to turbulence is much smaller than that owing to swimming, which in turn is only about a $0.8 \%$ increase with respect to molecular diffusion alone (Eq. 16 in Karp-Boss et al. 1996). See Lazier \& Mann (1989), Kiørboe (1993), and Karp-Boss et al. (1996) for in depth treatments of the effects of fluid motion on nutrient fluxes to osmotrophs. Based on these theoretical considerations, our first hypothesis is that reasonable levels of turbulence do not affect bacterial growth and activity.

However, bacteria do not live alone in the environment, but form part of a community of many different taxa presenting a complicated web of material and energy interactions. Phytoplankton cells have basically the same nutrient flux constraints as bacteria, although light can become an additional limiting factor (Thompson et al. 1989, for example). Phytoplankton, especially the larger size fractions, could substantially benefit from turbulence (Karp-Boss et al. 1996). If phytoplankton growth is enhanced, grazers of phytoplankton should benefit from increased food availability. This trophic interaction results in nitrogen and phosphorus recycling since the grazing heterotrophs have to respire part of the carbon with a certain efficiency (Caron \& Goldman 1990). In turn, bacteria could benefit from increased nutrient concentrations. Additional nutrient sources can become available to bacteria through phytoplankton excretion and through sloppy feeding by micro- and mesozooplankton.

Experimental studies of phytoplankton growth under turbulence are again limited. Savidge (1981) found higher cell yields under turbulence when the cultures were phosphorus limited. Berdalet (1992) showed that Gymnodinium nelsonii stopped dividing and increased in size under turbulence. Thomas et al. (1995) found that the dinoflagellate Gonyaulax polyedra showed in general lower growth rates, lower photosynthetic rates, and higher respiration rates in Couette cylinders. Higher respiration rates, when not translated into growth, would result into higher nitrogen $(\mathrm{N})$ and phosphorus $(\mathrm{P})$ recycling rates. Hence, evidence points towards an overall effect of increased nutrient availability that bacteria could take advantage of to increase their growth.

The objective of this study is to test experimentally whether turbulence can increase bacterial growth through effects at higher trophic levels, which would cascade down to increase the nutrient field. As mentioned earlier, turbulence should have a negligible direct effect on the nutrient diffusion to and away from bacteria-sized cells. Our prediction is that turbulence will only alter bacterial dynamics through food web interactions, while the absence of the microbial food web (other than bacteria) will prevent any effects from. turbulence.

\section{MATERIALS AND METHODS}

Water sampling and experimental design. We performed 2 experiments with NW Mediterranean coastal water, monitoring bacterial growth and activity. One experiment was conducted at a level of turbulence relevant to coastal waters, and the other experiment was conducted at a higher level. Each experiment had a still-water reference and consisted of treatments with the whole microbial community and with the presence of bacteria only.

Water for the experiments was taken from the Catalan coast (Masnou, NW Mediterranean, $20 \mathrm{~km}$ north of Barcelona, Spain) ca $1 \mathrm{~km}$ offshore. We filled two $20 \mathrm{l}$ containers with surface water from $0.5 \mathrm{~m}$. The containers had been washed with a dilute solution of sodium hypochloride and thoroughly rinsed 3 times with tap water, deionized water, and finally with sample water. Surface water temperature was measured before sampling. Table 1 summarizes the timing and source-water conditions of these experiments.

We brought the seawater within $45 \mathrm{~min}$ to the laboratory, where we screened it through a $150 \mu \mathrm{m}$ Nylon mesh to eliminate mesozooplankton that could bias the results in the experimental containers. Additionally, we were interested in the indirect effects of the microbial community on bacterial growth, while we already had a fair understanding of the effects of turbulence on larger organisms (Marrasé et al. 1990, Saiz \& Alcaraz 1992, Saiz et al. 1992, Kiørboe \& Saiz 1995). Several liters were additionally filtered through $0.8 \mu \mathrm{m} \mathrm{MF-}$ Millipore cellulose ester filters for the bacteria-only treatment. To wash out possible contaminants in the filter, the first $500 \mathrm{ml}$ of filtrate from new filters was discarded.

Table 1. Summary of conditions during seawater sampling and during the experimental runs

\begin{tabular}{|lcc|}
\hline & Expt 1 & Expt 2 \\
\hline Seawater conditions & & \\
Date & Jan 28, 1997 & Feb 17, 1997 \\
Time & $10: 15 \mathrm{~h} \mathrm{GMT}$ & $09: 00 \mathrm{~h} \mathrm{GMT}$ \\
Temperature $\left({ }^{\circ} \mathrm{C}\right)$ & 12 & 12.5 \\
Light intensity $\left(\mu \mathrm{E} \mathrm{m}^{-2} \mathrm{~s}^{-1}\right)$ & & \\
Air & - & 1250 \\
Sea surface $(0 \mathrm{~m})$ & 100 & 400 \\
Subsurface $(25 \mathrm{~cm})$ & 80 & 320 \\
Sea state $($ Beaufort scale) & 2 & $0-1$ \\
Experimental conditions & & \\
Temperature $\left({ }^{\circ} \mathrm{C}\right)$ & 14 & 14 \\
Light intensity $\left(\mu \mathrm{E} \mathrm{m} \mathrm{m}^{-2} \mathrm{~s}^{-1}\right)$ & 250 & 250 \\
Grid oscillation frequency $(\mathrm{rpm})$ & 3.8 & 20 \\
Energy dissipation rate $\left(\mathrm{cm}^{2} \mathrm{~s}^{-3}\right)$ & 0.07 & 11 \\
\hline
\end{tabular}


We placed 11 of water in each of 8 containers, 4 of them with $150 \mu \mathrm{m}$ screened water and 4 of them with $0.8 \mu \mathrm{m}$ filtered water (named 150 and 0.8 respectively hereafter). The containers were 11 borosilicate glass beakers that previously had been acid washed and autoclaved. Two of each treatment were agitated to create turbulence and the other 2 were left still (named $\mathrm{T}$ and $\mathrm{S}$ respectively hereafter). The experiments were conducted in an environmental chamber at $14 \pm 1^{\circ} \mathrm{C}$ and under a $12 \mathrm{~h}$ light: $12 \mathrm{~h}$ dark cycle. Light intensity was $250 \mu \mathrm{E} \mathrm{m}^{-2} \mathrm{~s}^{-1}$ from an equal mixture of coolwhite and gro-lux fluorescent lamps.

Turbulence generation. In the ocean, small-scale turbulence originates from energy inputs into the system mainly at the 1 to $10 \mathrm{~m}$ scale. In the surface mixed layer this energy input corresponds mostly to gravity waves. In coastal waters, tidal movements and bottom roughness can generate additional turbulent motion. The eddy motion derived from these energy inputs is transferred to ever smaller eddy scales until viscosity damps out the smallest velocity fluctuations. The theoretical scale where eddy and viscous forces equal each other is known as the Kolmogorov microscale, which for space is calculated as $\lambda_{k}=\left(v^{3} / \varepsilon\right)^{1 / 4}$, where $v\left(\mathrm{~cm}^{2} \mathrm{~s}^{-1}\right)$ is the kinematic viscosity of seawater and $\varepsilon\left(\mathrm{cm}^{2} \mathrm{~s}^{-3}\right)$ is the turbulent kinetic energy dissipation rate, a measure of turbulence intensity. Strictly speaking we have smallscale turbulence only down to around $\lambda_{k}$, which in the ocean ranges normally from ca 0.7 to $0.07 \mathrm{~cm}$, depending on the energetic conditions (calculated from Mackenzie \& Leggett 1993). Below this size, water motion is said to be characterized by the remaining laminar shear field derived from the eddies. In this paper we use the term 'small-scale turbulence' in a broad sense, including motions below the Kolmogorov microscale, unless specifically mentioned otherwise.

Turbulence was introduced with vertically oscillating grids with an apparatus similar to that described before (Peters \& Gross 1994). The grids were made of non-toxic plastic with a mesh size of $0.6 \mathrm{~cm}$ and a bar thickness of $0.35 \mathrm{~cm}$. The shafts $(0.3 \mathrm{~cm} \varnothing)$ were made of solid stainless steel and the grids were held in place with stainless steel nuts.

The estimation of average turbulent kinetic dissipation rate introduced in the containers was done with the theoretical calculations outlined in Peters \& Gross (1994). The levels of turbulence were chosen to simulate a storm event in coastal waters (Expt 1,4 rpm oscillation frequency, $0.07 \mathrm{~cm}^{2} \mathrm{~s}^{-3}$ ) and to approach the turbulence levels used in most previous experiments (Expt 2, $20 \mathrm{rpm}$ oscillation frequency, $11 \mathrm{~cm}^{2} \mathrm{~s}^{-3}$ ). The 2 frequencies were achieved with interchangeable fixed speed AC gear head motors.

Parameters measured. Water was sampled from the containers each day for analysis of different parame- ters. We sampled small volumes (18 ml or less) to avoid reducing significantly the volume in the container. Larger volumes were sampled at time zero and at the end of the experiment.

Subsamples were fixed for microscopy with $10 \%$ cold glutaraldehyde for a final concentration of $1 \%$ glutaraldehyde. Bacteria and heterotrophic (colorless) flagellates were counted on black polycarbonate filters $(0.2 \mu \mathrm{m}$ for the bacteria and $0.8 \mu \mathrm{m}$ for the flagellates) following the DAPI-staining method of Porter \& Feig (1980), with a final concentration of DAPI of $5 \mu \mathrm{g} \mathrm{m} \mathrm{m}^{-1}$. We used a Nikon Labophot epifluorescence microscope at $1250 \times$ magnification. Samples for flagellates could be taken only at the beginning and end of the experiment. Flagellates were sized using a calibrated ocular micrometer.

Daily samples for flow cytometry $(1.5 \mathrm{ml})$ were fixed with $0.15 \mathrm{ml}$ of a $10 \%$ paraformaldehyde and $0.5 \%$ glutaraldehyde mixture and stored frozen at $-80^{\circ} \mathrm{C}$. At the time of determination, samples were thawed and run through a FACScalibur (Becton \& Dickinson) flow cytometer with a laser emitting at $488 \mathrm{~nm}$.

For bacteria, the sample was first stained with SYTO13 (Molecular Probes) at $1.6 \mu \mathrm{M}$. Samples were run at low flow speed (approx. $12 \mu \mathrm{min}^{-1}$ ) and data were acquired in $\log$ mode until about 10000 events had been acquired. As an internal standard, we usually added $10 \mu \mathrm{l}$ per sample of a $10^{6} \mathrm{ml}^{-1}$ solution of yellow-green $0.92 \mu \mathrm{m}$ latex beads (Polysciences). Bacteria were detected by their signature in a plot of side light scatter versus green fluorescence. This method is based on that published by del Giorgio et al. (1996).

For phytoplankton, samples were left unstained. The running specifications were the same as those for bacteria, except that samples were run at high flow speed (approx. $60 \mu \mathrm{min}^{-1}$ ) and internal standard beads were added at a lower concentration $\left(10^{5} \mathrm{ml}^{-1}\right.$ final). Synechococcus was detected by its signature in a plot of orange fluorescence (FL2) versus red fluorescence (FL3). Prochlorococcus has a lower FL3 signal and no FL2 signal. Eukaryotic picoplankton have higher FL3 signals and no FL2 signals. Nanoeukaryotes have much higher FL3 signals. Further details are described in Olson et al. (1.993).

The rate of incorporation of tritiated leucine into protein was used as an estimate of bacterial activity. We used the method of Kirchman et al. (1985) as described in Kirchman (1993) with the Smith \& Azam (1992) modifications. Tritiated leucine from Amersham $1151 \mathrm{mCi}$ $\mathrm{mmol}^{-1}$ ) was brought to $1 \mu \mathrm{M}$, mixed with nonradioactive leucine at 10\% hot: $90 \%$ cold, and dispensed to $1.2 \mathrm{ml}$ samples for a final concentration of $40 \mathrm{nM}$, which was enough to saturate incorporation according to our previous experience in the area. We used 4 replicates and 2 TCA-killed controls per sample and 
we incubated them for $2 \mathrm{~h}$ in the dark at $14^{\circ} \mathrm{C}$. The incorporation was stopped with 50\% TCA and rinsed twice by centrifugation in 5\% TCA. Optiphase Hisafe II scintillation cocktail was added before counting in a Packard scintillation counter.

Chlorophyll a concentration was determined by fluorometry (Yentsch \& Menzel 1963), after filtration of $50 \mathrm{ml}$ of sample on Whatman GF/F glass fiber filters and homogenization of the filters in $90 \%$ acetone.

Samples for nutrients (phosphate [soluble reactive phosphorus, SRP], nitrate + nitrite, nitrite and ammonium) were taken at the beginning and at the end of the experiments and analyzed with an Evolution II (Alliance Instruments) autoanalyzer following the procedures of Grasshoff et al. (1983) with minor modifications.

\section{RESULTS}

\section{Starting conditions}

Conditions at the beginning of the 2 experiments were quite different. Expt 1 had an N:P of 46 with high levels of nitrate $(6 \mu \mathrm{M})$ and ammonium $(1 \mu \mathrm{M})$ and relatively low chlorophyll a $\left(1 \mu \mathrm{g} \mathrm{I}^{-1}\right)$. Expt 2 was started 3 wk later with an N:P of 18 , basically because of lower levels of the $N$ pool, and chlorophyll a concentrations of $3 \mu \mathrm{g} \mathrm{l}^{-1}$ (Table 2). We had a week of stormy weather before sampling water for Expt 1, producing resuspension of nutrients from the sediments and nutrient input from terrestrial run-off. Chlorophyll a and bacterial concentrations were relatively low because they had not had time to respond to the increased nutrient conditions. We did not see much difference in the P concentration, probably because $\mathrm{P}$ was the limiting nutrient. Thingstad \& Rassoulzadegan (1995) argue that P is limiting in this part of the Mediterranean and explain it by high P turnover rates (Dolan et al. 1995). During the time between Expt 1 and Expt 2 the weather was relatively calm. Organisms had been able to respond to the higher nutrient concentrations with the result that the seawater nutrient pool was reduced and biomass had increased (Table 2).

An additional difference in the starting conditions within each experiment came from the filtration, which allowed only $30 \%$ of the bacterial concentration to pass through the $0.8 \mu \mathrm{m}$ filters. It also increased the $\mathrm{P}$ and $\mathrm{NH}_{4}{ }^{+}$concentration in Expt 2, most likely owing to the breakdown of some large phytoplankton cells. Despite these differences, we were able to compare the effect of turbulence with respect to the still-water control for each filtered fraction and then compare the magnitude of the effects between fractions.

\section{Bacterial abundance and activity}

Since flow cytometry and DAPI counts of bacteria gave an almost $1: 1$ correlation (cytometry $=-10^{4}$ cells $\mathrm{ml}^{-1}+0.97 \mathrm{DAPI} ; \mathrm{N}=80, \mathrm{R}^{2}=0.91, \mathrm{p}<0.0001$ ), we used cytometry data in all subsequent graphs and analyses. In all experimental containers bacteria increased their concentration significantly, at least during the first day (Fig. 1). Since the 0.8 treatments relieved the grazing pressure on bacteria, reduced the bacterial concentra-

Table 2. Chlorophyll $a$ and dissolved inorganic nutrient data at the beginning $\left(T_{i m e}\right.$ ) and end (Time final of Expts 1 and 2 . The experimental treatments are found in the different colums based on the 0.8 and $150 \mu \mathrm{m}$ size cut-offs and turbulence (T) and stillwater (S) treatments. Values are average and SE (In parentheses) of 2 replicates. Units for chlorophyll $a$ are in $\mu g I^{-1}$ and for nutrients are in $\mu \mathrm{M}$. SRP: soluble reactive phosphorus

\begin{tabular}{|c|c|c|c|c|c|c|}
\hline & 0.8 & Time $_{0}$ & T0.8 & S0.8 & $T 150$ & $\mathrm{~S} 150$ \\
\hline \multicolumn{7}{|l|}{ Expt 1} \\
\hline Chl a & $-^{d}$ & $0.91(0.013)$ & $0.01(0.000)$ & $0.09(0.020)$ & $0.90(0.075)$ & $0.95(0.275)$ \\
\hline SRP & $0.20(0.005)$ & $0.16\{0.015\}$ & $0.18(0.010)$ & $0.23(0.003)$ & $0.15(0.003)$ & $0.22(0.010)$ \\
\hline $\mathrm{NO}_{3}^{-}$ & $5.69(0.385)$ & $5.54(0.085)$ & $4.77(0.384)$ & $4.65(0.080)$ & $4.26(0.212)$ & $4.15(0.239)$ \\
\hline $\mathrm{NO}_{2}^{-}$ & $0.39(0.000)$ & $0.39(0.010)$ & $1.00(0.032)$ & $0.29(0.009)$ & $1.17(0.000)$ & $0.22(0.006)$ \\
\hline $\mathrm{NH}_{4}^{+}$ & $1.03(0.010)$ & $1.1 .5(0.125)$ & $0.95(0.070\}$ & $0.10(0.019)$ & $1.46(0.188)$ & $0.17(0.092)$ \\
\hline \multicolumn{7}{|l|}{ Expt 2} \\
\hline Chl a & -4 & $2.94(0.130)$ & $0.07^{\circ}$ & $0.09(0.025)$ & $1.76(0.1 .60)$ & $3.36(0.020)$ \\
\hline SRP & $0.29(0.005)$ & $0.09(0.002)$ & $0.11^{b}$ & $0.17(0.011)$ & $0.02(0.003)$ & $0.04(0.003)$ \\
\hline $\mathrm{NO}_{3}^{-}$ & $1.06(0.035)$ & $1.57(0.205)$ & $2.36^{b}$ & $1.70(0.039)$ & $1.67(0.11 .5)$ & $0.75(0.072)$ \\
\hline $\mathrm{NO}_{2}^{-}$ & $0.11\{0.010\}$ & $0.11(0.003)$ & $0.88^{b}$ & $0.10(0.006)$ & $0.82(0.028)$ & $0.08(0.006)$ \\
\hline $\mathrm{NH}_{4}{ }^{+}$ & $0.13(0.020)$ & $0.02(0.003)$ & $3.06^{b}$ & $0.51(0.190)$ & $2.20(0.181)$ & $0.08(0.026)$ \\
\hline
\end{tabular}



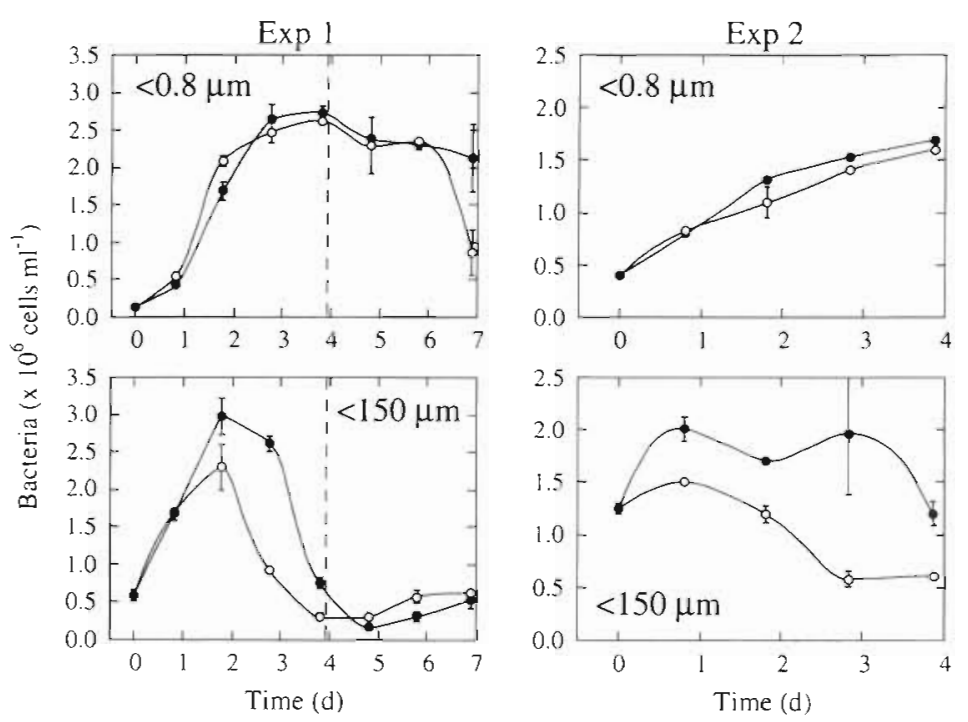

Fig. 1. Abundance of bacteria in the $0.8 \mu \mathrm{m}$ and the $150 \mu \mathrm{m}$ size cut-off treatments. (-) Turbulence treatments; (O) still-water treatments. Symbols are means of 2 replicates and error bars are \pm 1 SE. When no error bars are present, SE is contained within the symbol boundaries, except in Expt 2, where there was only 1 turbulence replicate of the $0.8 \mu \mathrm{m}$ treatment. The dashed line in Expt 1 is for comparison with Expt 2 and to denote the limit for the time factor used in statistıcal analyses part, and especially for the initial $4 \mathrm{~d}$, not different between turbulent and non-turbulent treatments (Table 3 ).

\section{Other planktonic microorganisms}

These organisms, being larger than bacteria, obviously should be found only in the 150 treatments, and we note the exceptions where needed. Synechococcus-like cells (Figs. 4 \& 5) decreased their concentration during the experiments. In Expt 1, where the initial numbers were fairly low $\left(10^{3}\right.$ cells $\left.\mathrm{ml}^{-1}\right)$, the decrease over time was drastic, with these cells basically disappearing after 4 d (Fig. 4). Expt 2, on the other hand, started with higher concentrations and, after an initial increase, the concentration decreased to about one third after $4 \mathrm{~d}$ (Fig. 5). These dynamics seem to have fairly little to do with turbulence, since they occurred both with and without it, and are probably the result of grazing.

Pigmented pico- and nanoeukaryotes showed consistently higher concentrations in the still-water treatment, reaching values 5 times the initial ones. In Expt 1 the differ- tion and were somewhat enriched with nutrients (especially in Expt 2), bacteria grew faster and maintained higher concentrations for a longer time than in the 150 treatments (Fig. 1).

The concentration and activity of bacteria in the 0.8 treatments were not directly affected by either of the turbulence levels tested for the first 4 d (Figs. 1 \& 2). After that time, some differences started to appear. On the contrary, in the 150 treatments, marked differences appeared between Days 1 and 2 (Figs. 1 \& 2) owing to turbulence, indicating an effect produced indirectly through food web interactions. Bacteria in the turbulent treatments achieved higher concentrations and remained for several days at higher concentrations than in the still treatment. Bacterial concentration was 51 to $68 \%$ greater under turbulence. Bacterial activity followed an almost identical pattern (80 to $94 \%$ higher under turbulence). In Expt 1 this trend reversed after $4 \mathrm{~d}$ in the 150 treatment, and bacterial concentration and activity were then higher in still water (Figs. $1 \& 2$ ).

The differences in bacterial activity were not due to changes in specific per cell activity (Fig. 3), which was for the most
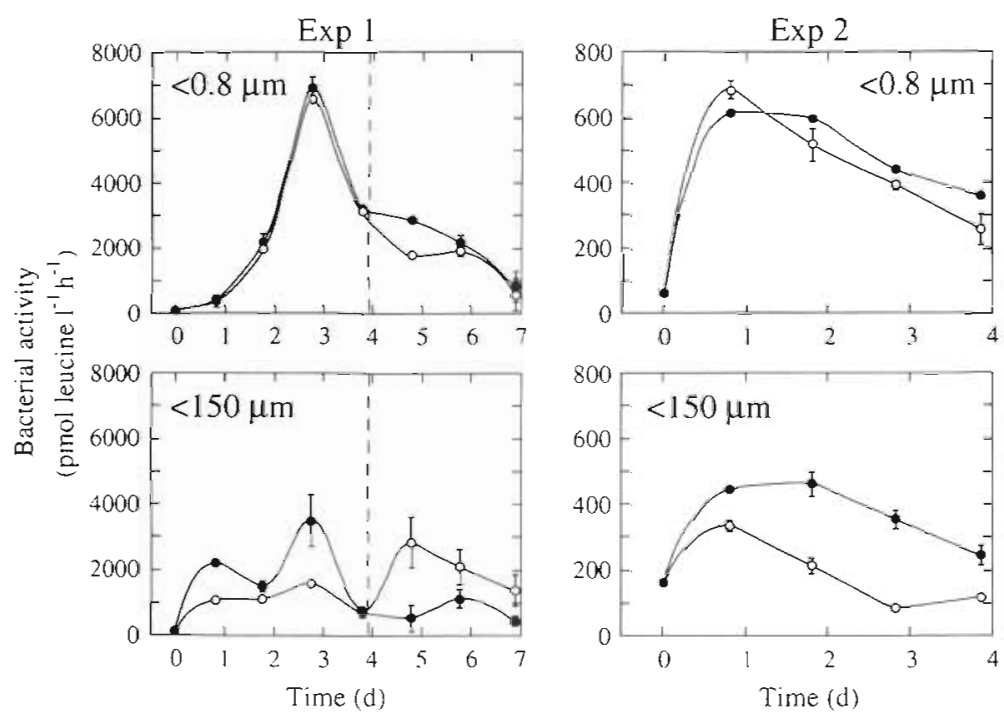

ences persisted for $7 \mathrm{~d}$, to the end of the experiment (Fig. 4), while in Expt 2 (Fig. 5) the concentrations seemed to come together after $4 \mathrm{~d}$. Final concentrations of picoeukaryotes in Expt 2 were slightly lower than initial ones.

Heterotrophic flagellates increased in all treatments. In Expt 1 there were no significant differences be-
Fig. 2. Uptake rates of leucine in the $0.8 \mu \mathrm{m}$ and the $150 \mu \mathrm{m}$ size cut-off treatments. Symbols and error bars as in Fig. 1 

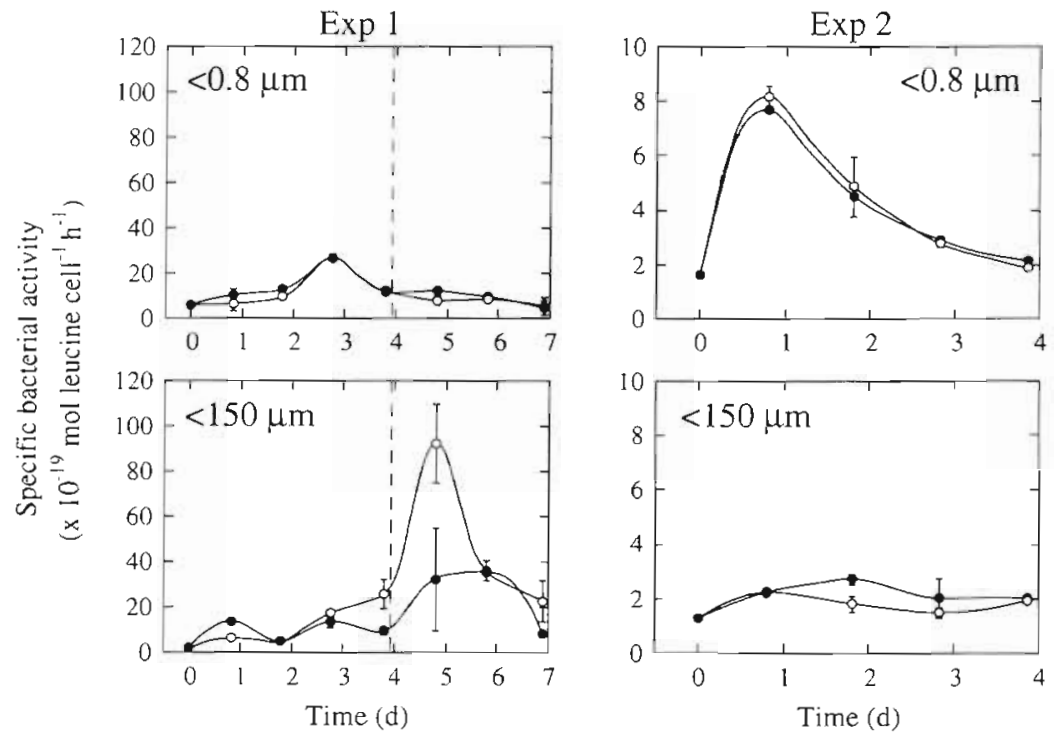

Fig. 3. Cell specific uptake rates of leucine in the $0.8 \mu \mathrm{m}$ and the $150 \mu \mathrm{m}$ size cut-off treatments. Symbols as in Fig. 1

tween $\mathrm{S}$ and $\mathrm{T}$ by the end of the experiment, while in Expt 2 turbulence enhanced flagellate growth (Fig. 6). Flagellate size also increased in all treatments from $3.55 \mu \mathrm{m}$ ESD (equivalent spherical diameter) by an average of $11 \pm 1.8 \%$. The 4 to $8 \mu \mathrm{m}$ size fraction increased 65 and $53 \%$ more in the turbulent treatment than in still water by the end of Expts 1 and 2 respectively (Fig. 6).

\section{Chlorophyll and nutrients}

Chlorophyll a did not show a clear pattern (Table 2). In Expt 1 it remained at initial levels after $7 \mathrm{~d}$ in the 150 treatment. Prochlorococcus-like cells and some pigmented picoautotrophs appearing in S0.8 accounted for the significant increase in chlorophyll in that treatment. In Expt 2 chlorophyll was lower in T150 and higher in S150 after $4 \mathrm{~d}$, despite their having similar final concentrations of pico- and nanophytoplankton (Fig. 5).

The concentrations of phosphate at the end of experiments tended to be lower in the $\mathrm{T}$ treatments with respect to their $\mathrm{S}$ controls. Nitrate, in contrast, was unchanged or higher under turbulence. Phosphate in Expt 2 showed final concentrations that were significantly lower than initial values. The most striking result for nutrients is that nitrite concentrations were very high at the end of the experiments in the $\mathrm{T}$ treatments. Ammonium concentrations were also much higher in $\mathrm{T}$ than in $\mathrm{S}$. This

Table 3. Two-way ANOVAs of bacterial concentration (cells $\mathrm{ml}^{-1}$ ), uptake rates (pmol leucine $\mathrm{l}^{-1} \mathrm{~h}^{-1}$ ), and specific uptake rates $\left(\times 10^{-19}\right.$ mol leucine cell $\left.{ }^{-1} \mathrm{~h}^{-1}\right)$, taking turbulence (turb) and time as factors. In Expt 1, only the points for the first $4 \mathrm{~d}$ are taken as levels for the time factor. Numbers are probability values; ns: non-significant $(p>0.05)$

\begin{tabular}{|c|c|c|c|c|}
\hline & \multicolumn{2}{|c|}{ Expt 1} & \multicolumn{2}{|c|}{ Expt 2} \\
\hline \multicolumn{5}{|c|}{ Bacterial concentration } \\
\hline \multirow[t]{3}{*}{$0.8 \mu \mathrm{m}$} & Turb & ns & Turb & ns \\
\hline & Time & $<0.001$ & Time & 0.015 \\
\hline & Turb $\times$ Time & ns & Turb $\times$ Time & ns \\
\hline \multirow[t]{3}{*}{$150 \mu \mathrm{m}$} & Turb & $<0.001$ & Turb & 0.001 \\
\hline & Time & $<0.001$ & Time & 0.024 \\
\hline & Turb $\times$ Time & 0.003 & Turb $\times$ Time & ns \\
\hline \multicolumn{5}{|c|}{ Uptake rates } \\
\hline \multirow[t]{3}{*}{$0.8 \mu \mathrm{m}$} & Turb & ns & Turb & ns \\
\hline & Time & $<0.001$ & Time & 0.006 \\
\hline & Turb $\times$ Time & ns & Turb $\times$ Tinne & ns \\
\hline \multirow[t]{3}{*}{$150 \mu \mathrm{m}$} & Turb & 0.004 & Turb & $<0.001$ \\
\hline & Time & 0.002 & Time & $<0.001$ \\
\hline & Turb $\times$ Time & 0.050 & Turb $\times$ Time & 0.013 \\
\hline \multicolumn{5}{|c|}{ Specific uptake rates } \\
\hline \multirow[t]{3}{*}{$0.8 \mu \mathrm{m}$} & Turb & ns & Turb & ns \\
\hline & Time & $<0.001$ & Time & 0.020 \\
\hline & Turb $\times$ Time & ns & Turb $\times$ Time & nes \\
\hline \multirow[t]{3}{*}{$150 \mu \mathrm{m}$} & Turb & ns & Turb & ns \\
\hline & Time & 0.005 & Time & ns \\
\hline & Turb $\times$ Time & 0.012 & Turb $\times$ Time & ns \\
\hline
\end{tabular}



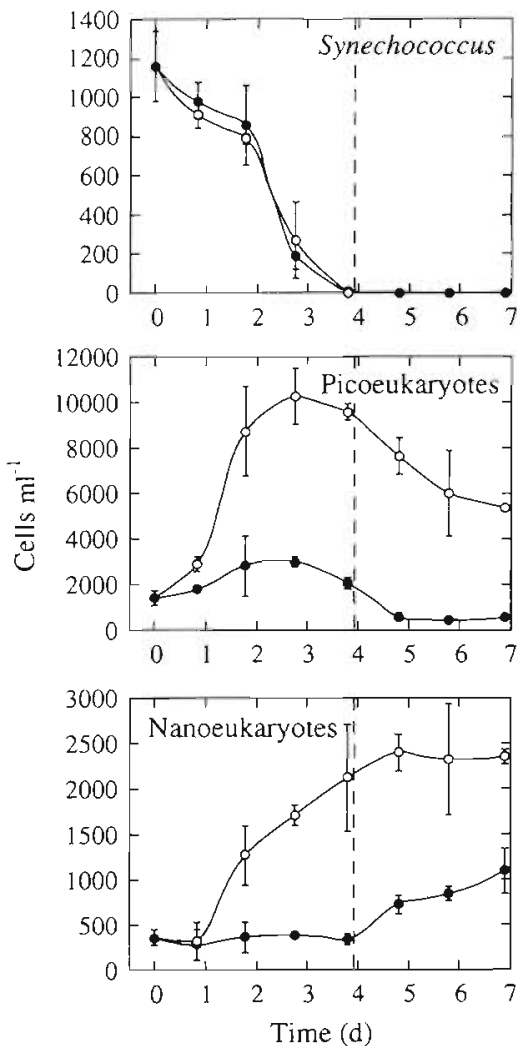

Fig. 4. Abundance of different pigmented microorganisms in the $150 \mu \mathrm{m}$ size cut-off treatments during Expt 1 (•) Turbulence treatments; (O) still-water treatments. Symbols are means of 2 replicates and error bars are $\pm 1 \mathrm{SE}$. When no error bars are present, SE is contained within the symbol boundaries

points towards a higher recycling rate of dissolved organic matter under turbulence (see 'Discussion').

\section{DISCUSSION}

\section{Bacterial response to turbulence}

Supporting our initial hypothesis, in conditions where only bacteria were present (upper panels of Figs. 1 \& 2), neither bacterial abundance nor activity were affected by turbulence even at high levels (ca $10 \mathrm{~cm}^{2} \mathrm{~s}^{-3}$ ). After 3 or $4 \mathrm{~d}$, some non-bacterial growth was observed in the experimental containers, either due to contamination during the experiment (unlikely since we were very careful to use clean techniques and to avoid cross-contamination) or most likely due to the growth of residual organisms passing through the $0.8 \mu \mathrm{m}$ filter. This growth introduced an uncontrolled factor which probably affected the growth and mortality of bacteria, and we no longer could clearly assess the direct effect of turbulence on bacteria. For the ini-
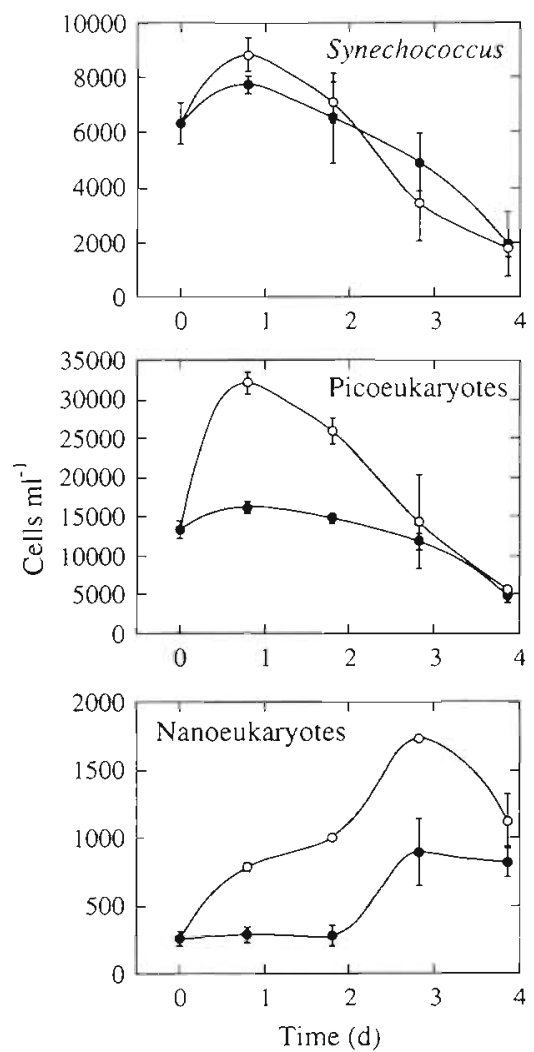

Fig. 5. Abundance of different pigmented microorganisms in the $150 \mu \mathrm{m}$ size cut-off treatments during Expt 2. Symbols as in Fig. 4
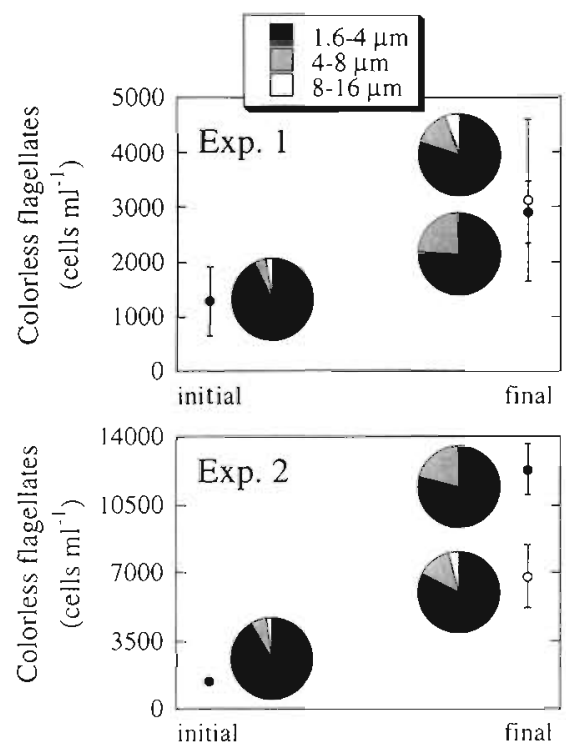

Fig. 6. Initial and final abundance of colorless flagellates as counted by epifluorescence microscopy of DAPI-stained samples in the $150 \mu \mathrm{m}$ size cut-off treatment. ( ) Turbulence treatments; (O) still-water treatments. Symbols are means of 2 replicates and error bars are $\pm 1 \mathrm{SE}$. When no error bars are present, SE is contained within the symbol boundaries. Pie charts show the proportion of different size classes 
tial days, the contribution of these organisms was minimal since their numbers were undetectable, and we can consider turbulence as the only variable in the experiment.

Our initial hypothesis was based on theoretical considerations. The concentration of nutrients far away from a bacterium should not have been increased through turbulence levels of 0.07 to $11 \mathrm{~cm}^{2} \mathrm{~s}^{-3}$ Probably, the scales at which hydrodynamic motion starts affecting the nutrient field are still larger than the bacterial size plus the radius of the nutrient field generated by the bacterium around it. Moeseneder \& Herndl (1995) also found that bacterial activity was unaffected by turbulence when other planktonic organisms were absent. They also found that, in the presence of algae, bacterial activity was mostly negatively affected by turbulence, and argued that turbulence homogenized the nutrient field so that there would be no gradients to enable chemotaxis to direct bacteria to nutrient-rich micropatches. Their experimental containers were $14 \mathrm{ml} \mathrm{Falcon}$ tubes and the levels of turbulence used were 30 to $3 \times 10^{3}$ times larger than ours. It may be possible that under such conditions turbulence could directly affect the nutrient field around bacteria as they suggested. In any case, from this study, with much larger experimental volumes and a more realistic turbulence level $\left(0.07 \mathrm{~cm}^{2} \mathrm{~s}^{-3}\right)$, we cannot corroborate Moeseneder \& Herndl.'s findings.

Confer \& Logan (1991) found higher uptake rates of high molecular weight substrates under very strong shear levels $\left(200 \mathrm{~s}^{-1}, \varepsilon=400 \mathrm{~cm}^{2} \mathrm{~s}^{-3}\right)$. Logan \& Kirchman (1991) found somewhat higher uptake rates of low molecular weight substrates when bacteria were exposed to shear levels above $2.1 \mathrm{~s}^{-1}\left(\varepsilon=0.04 \mathrm{~cm}^{2} \mathrm{~s}^{-3}\right)$, while below this level no effect was found. Logan \& Kirchman (1991) concluded that naturally occurring shear levels would be ineffective in changing the nutrient field around bacteria. In summary, when the previous data are analyzed in detail, they do not disagree with the resuits from this study. No direct effect of turbulence on bacterial abundances or activity is found at naturally occurring turbulence levels

Differential sedimentation of bacteria between the turbulent and non-turbulent treatments was not significant. We analyzed possible sedimentation at the end of Expt 2 by comparing bacterial abundances before and after homogenizing the experimental containers $(p=0.549)$. Had sedimentation been important, abundances should have been significantly higher after homogenization, but they were not, neither in the turbulent nor in the still water treatments. Thus, differential bacterial sedimentation could not account for any of the bacterial population dynamics observed. Some sedimentation of large phytoplankton may have occurred both in the still and turbulent containers.
Although one would expect a higher sedimentation rate of large phytoplankton in the still containers, the higher chlorophyll values in $\mathrm{S} 150$ by the end of Expt 2 do not confirm this.

One piece of data, namely the levels of ammonium and nitrite at the end of the experiments, is puzzling at first glance. Ammonium and nitrite showed much higher levels under turbulence than in still water, no matter whether the rest of the microbial community was present or not. The cause for the high levels of these nutrients seems to be a higher recycling rate of dissolved organic matter under turbulence. Surprisingly, however, this process seems to be largely uncoupled from the particulate dynamics of bacteria, at least in the time frame of our experiments, since there were no differences in bacterial growth in the 0.8 treatments. An extraneous source of ammonium being mixed inside the containers more efficiently under turbulence is highly unlikely given the placement and conditions of the experiments in our environmental chamber, but this cannot be completely discarded without dissolved organic nitrogen data to assess nitrogen budgets.

There is evidence that when the colloidal organic carbon/matter (COC) fraction of the DOM (dissolved organic matter) is incorporated into microaggregates, episodes of high respiration and exoenzymatic activity are triggered, which are largely uncoupled from bacterial growth and production (see Kepkay [1994] for a review). This may have happened in the turbulent treatments. The question of how turbulence changes the DOM matrix and how in turn this might change the availability of different organic matter fractions to bacteria (Azam 1998) should be an interesting subject for future investigations. In any case, these changes did not affect the abundance and activity of bacteria, at least not during our incubations.

\section{Turbulence and trophic interactions}

When the microbial community was present, bacterial growth and activity was enhanced for several days under turbulence. However, the mechanism outlined in the introduction for this increase, that is, a higher phytoplankton growth rate, resulting in a higher grazing response and an increase of regenerated nutrients available to bacteria, seems to be incorrect or incomplete.

Cell specific activity showed little or no differences between turbulent and non-turbulent treatments (Fig. 3, Table 3). Hence, differences in bacterial abundance and uptake rates ( $p m o l$ leucine $\mathrm{I}^{-1} \mathrm{~h}^{-1}$ ) had to be the consequence of factors external to the bacterial community, and were most likely due to differential 
grazing pressure on bacteria. Grazing on bacteria in these experiments must have been lower under turbulence to result in higher bacterial abundances when cell specific bacterial activity did not increase differentially. Previous experiments of microflagellate grazing on bacteria under turbulence have been done mostly with cultures and have shown mixed results. Shimeta et al. (1995) found higher ingestion rates under a constant shear rate for some protozoan cultures tested, while there was a negative effect or no effect for other species. On the other hand, Peters \& Gross (1994) found that community grazing rates on bacteria were higher under high turbulence even if per cell ingestion rates did not change significantly (Peters et al. 1996).

The dynamics of pigmented pico- and nanoeukaryotes also showed differences in relation to turbulence Owing to their size $(<60 \mu \mathrm{m})$, they should theoretically not be affected by the levels of turbulence introduced If anything, we would have predicted turbulence to increase nutrient flux, thus enhancing phytoplankton growth. But the data show the contrary (Figs. 4 \& 5) The lower abundances of pico- and nanoeukaryotic algae under turbulence again suggest a role for grazing. Grazing on small phytoplankton must have been enhanced under turbulence.

But how could turbulence differentially affect the grazing rates on bacterio- and phytoplankton? The shear field present below Kolmogorov microscales can enhance encounter rates between protozoans and their prey particles (Shimeta et al. 1995), especially at the fairly high turbulence levels used in this study. For protozoans feeding on a range of food particle sizes, the increase in encounter rate with respect to still water is the same for the different prey size classes (Eq. 3, Shimeta et al. 1995). Given a choice, larger prey are very likely to be preferred since the volume ingested increases as a cube of prey radius. Some protozoans have been shown to be very versatile in ingesting food particles of different sizes and nutritional quality (Goldman \& Caron 1985, Suttle et al. 1986, Verity 1991). Furthermore, it seems that protozoans, and especially small flagellates, generally prefer larger particles (Andersson et al. 1986, Gonzalez et al. 1990, Epstein \& Shiaris 1992, Peters 1994) and particles with high nutritional value (Verity 1991). If encounter rates of bacteria and small algae with microflagellates were increased through shear, the flagellates could have chosen to prey more on the larger and more nutritious particles (algae) and reduce the grazing pressure on the less preferred smaller particles (bacteria). The 4 to $8 \mu \mathrm{m}$ ESD fraction of the heterotrophic flagellates, which increased more under turbulence in both experiments (Fig. 6), could be responsible for keeping the pico- and nanophytoplankton low in that treatment.
Alternative scenarios to explain the dynamics of the populations in the experiments seem less likely. We might hypothesize that turbulence interferes with the growth of small phytoplankton or even that turbulence breaks cells and causes death. Nutrients in the medium would indeed increase through phytoplankton death and bacteria could benefit from them. But, even if phytoplankton did not grow as much under turbulence as in still water, the dynamics do not seem to be those of death curves. Indeed, phytoplankton increased in number under turbulence, at least initially. For nanophytoplankton, which by being larger than picophytoplankton would theoretically be more affected by turbulence, growth was never negative

The crash of the Synechococcus-like population in Expt 1 (Fig. 4) and the significant decrease in Expt 2 (Fig. 5) is not turbulence related since it also happened under still-water conditions. It is possible that experimental light conditions or some other factor related to the experimental set up was not appropriate for the growth of these organisms, although grazing could also account for these dynamics.

Based on the chlorophyll a data at the end of Expt 2 (Table 2), some large phytoplankton may have been injured under such high turbulence, which would produce a nutrient input that bacteria could use to grow. If this was the case, we should have seen a significant increase in specific bacterial activity in the turbulent treatment (Fig. 3), which we did not see. Differential grazing on large phytoplankton could also account for the differences in chlorophyll $a$ between turbulent and still-water treatments in Expt 2. This would be in agreement with our initial hypothesis of an increased growth of bacteria under turbulence owing to a higher nutrient recycling caused by higher grazing rates on the large phytoplankton.

Some or all of the alternative mechanisms mentioned may have contributed to the observed bacterial dynamics in Expt 2. However, based on the similarity in the trends of both experiments and on the fact that bacterial specific activity was not affected by turbulence, we conclude that differences in grazing on the bacteria were the main factor explaining bacterial dynamics.

\section{Turbulence in coastal systems}

The level of turbulence used in Expt $2\left(11 \mathrm{~cm}^{2} \mathrm{~s}^{-3}\right)$ is probably found nowhere in the ocean except for the surf zone, while the turbulence used in Expt 1 $\left(0.07 \mathrm{~cm}^{2} 5^{-3}\right)$ is on the high side of turbulence that can be found in coastal systems (Peters \& Redondo 1997).

It is remarkable that all the differences between turbulent and still-water treatments showed the same 
trends in both experiments despite different starting conditions (Tables $1 \& 3$ ). This strongly supports turbulence as being the factor producing those trends.

One important aspect is that populations (Figs. 1, 4 \& 5) seem to go back to initial concentrations after some time. After the system is altered through turbulence, the community with all its internal feedbacks brings the system back to an equilibrium, overcoming the physical forcing. This may be very important to understanding natural system dynamics, where turbulence is rarely present at high levels for as long as 4 to $7 \mathrm{~d}$. Instead, bursts of turbulence, which may last for 1 or $2 \mathrm{~d}$, would increase the production of the system, decreasing the level of accumulated dissolved organic carbon (Thingstad et al. 1997).

In conclusion, our results indicate that turbulence does not directly increase bacterial growth and activity. An indirect, food-web mediated, effect of turbulence reaches bacteria by first affecting higher trophic levels. It appears that grazing by microflagellates shifts to larger organisms/size classes, resulting in higher bacterial abundances and activity and lower pico- and nano-algal abundances. This chain of events, which fits our present data, needs detailed experiments addressing each step of it to confirm its internal mechanics.

Acknowledgements. We thank captain Elías Barrenechea and the staff at the Masnou harbor for letting us use their boat and helping us with sampling, and Mercedes Castaño for laboratory assistance. Enric Saiz lent us the motors and other lab equipment. We are grateful to the rest of the MEDEA team for the stimulating discussions that led to these experiments. Marta Estrada and Jordi Camp gave us some good ideas. The comments and suggestions by Ted Packard, Thomas Kiorboe and 3 anonymous reviewers greatly improved previous versions of the manuscript. This work was supported by the commission of the European Communities grant MAS3-CT950016 and the Spanish grant DGCYT-PB95-0222-C02-01. F.P. was a Marie Curie Fellow.

\section{LITERATURE CITED}

Andersson A, Larsson U, Hagström $\AA$ (1986) Size-selective grazing by a microflagellate on pelagic bacteria. Mar Ecol Prog Ser 33:51-57

Azam F (1998) Microbial control of oceanic carbon flux: the plot thickens. Science 280:694-696

Berdalet $E$ (1992) Effects of turbulence on the marine dinoflagellate Gymnodinium nelsonii. J Phycol 28:267-272

Caron DA, Goldman JC (1990) Protozoan nutrient regeneration. In: Capriulo GM (ed) Ecology of marine protozoa. Oxford University Press, New York, p 283-306

Confer DR, Logan BE (1991) Increased bacterial uptake of macromolecular substrates with fluid shear. Appl Environ Microbiol 57:309.3-3100

Dolan J, Thingstad TF, Rassoulzadegan F (1995) Phosphate transfer between microbial size-fractions in Villefranche Bay (N.W. Mediterranean sea), France in autumn 1992.
Ophelia 41:71-85

del Giorgio PA, Bird DF, Prairie YT, Planas D (1996) Flow cytometric determination of bacterial abundance in lake plankton with the green nucleic acid stain SYTO 13. Limnol Oceanogr 41:783-789

Epstein SS, Shiaris MP (1992) Size-selective grazing of coastal bacterioplankton by natural assemblages of pigmented flagellates, colorless flagellates, and ciliates. Microb Ecol 23:211-225

Goldman JC, Caron DA (1985) Experimental studies on an omnivorous microflagellate: implications for grazing and nutrient regeneration in the marine microbial food chain. Deep-Sea Res 32:899-915

Gonzalez JM, Sherr EB, Sherr BF (1990) Size-selective grazing on bacteria by natural assemblages of estuarine flagellates and ciliates. Appl Environ Microbiol 56:583-589

Grasshoff K, Ehrhardt M, Kremling K (1983) Methods of seawater analysis, 2nd edn. Verlag Chemie, Weinheim

Jumars PA, Deming JW, Hill PS, Karp-Boss L, Yager PL, Dade WB (1993) Physical constraints on marine osmotrophy in an optimal foraging context. Mar Microb Food Webs 7 : 121-159

Karp-Boss L, Boss E, Jumars PA (1996) Nutrient fluxes to planktonic osmotrophs in the presence of fluid motion. Oceanogr Mar Biol Annu Rev 34:71-107

Kepkay PE (1994) Particle aggregation and the biological reactivity of colloids. Mar Ecol Prog Ser 109:293-304

Kiørboe T (1993) Turbulence, phytoplankton cell size, and the structure of pelagic food webs. Adv Mar Biol 29:1-72

Kiorbøe T, Saiz E (1995) Planktivorous feeding in calm and turbulent environments, with emphasis on copepods. Mar Ecol Prog Ser 122:135-145

Kirchman DL (1993) Leucine incorporation as a measure of biomass production by heterotrophic bacteria. In: Kemp P.F, Sherr BF, Sherr EB, Cole JJ (eds) Handbook of methods in aquatic microbial ecology. Lewis Publishers, Boca Raton, FL, p 509-512

Kirchman DL, K'nees E, Hodson R (1985) Leucine incorporation and its potential as a measure of protein synthesis by bacteria in natural aquatic systems. Appl Environ Microbiol 49:599-607

Kirchman DL, Suzuki Y, Garside C, Ducklow HW (1991) High turnover rates of dissolved organic carbon during a spring phytoplankton bloom. Nature 352:612-614

Lazier JRN, Mann KH (1989) Turbulence and the diffusive layers around organisms. Deep-Sea Res 36:1721-1733

Logan BE. Kirchman DL (1991) Uptake of dissolved organics by marine bacteria as a function of fluid motion. Mar Biol $111: 175-1.81$

Mackenzie BR, Leggett WC (1993) Wind-based models for estimating dissipation rates of turbulent energy in aquatic environments: empirical comparisons. Mar Ecol Prog Ser $94: 207-216$

Marrasé C, Costello JH, Granata T, Strickler JR (1990) Grazing in a turbulent environment: energy dissipation, encounter rates, and efficacy of feeding currents in Centropages hamatus. Proc Natl Acad Sci USA 87:1653-1657

Moeseneder MM: Herndl GJ (1995) Influence of turbulence on bacterial production in the sea. Limnol Oceanogr 40 : $1466-1473$

Olson RJ, Zettler ER, Durand MD (1993) Phytoplankton analysis using flow cytometry. In: Kemp PF, Sherr BF, Sherr EB, Cole JJ (eds) Handbook of methods in aquatic microbial ecology. Lewis Publishers, Boca Raton, FL, p $175-186$

Peters F (1994) Prediction of planktonic protistan grazing rates. Limnol Oceanogr 39:195-206 
Peters F, Choi JW, Gross $\Upsilon$ (1996) Paraphysomonas imperforata (Protista, Chrysomonadida) under different turbulence levels: feeding, physiology and energetics. Mar Ecol Prog Ser 134:235-245

Peters F, Gross T (1994) Increased grazing rates of microplankton in response to small-scale turbulence. Mar Ecol Prog Ser 115:299-307

Peters F, Redondo JM (1997) Turbulence generation and measurement: application to studies on plankton. Sci Mar 61(Suppl 1):205-228

Pomeroy LR, Sheldon JE, Sheldon WM Jr, Peters F (1995) Limits to growth and respiration of bacterioplankton in the Gulf of Mexico. Mar Ecol Prog Ser 117:259-268

Porter KG, Feig YS (1980) The use of DAPl for identifying and counting aquatic microflora. Limnol Oceanogr 25:943-948

Saiz E, Alcaraz M (1992) Enhanced excretion rates induced by small-scale turbulence in Acartia (Copepoda: Cala. noida). J Plankton Res 14:681-689

Saiz E, Alcaraz M, Paffenhöfer GA (1992) Effects of smallscale turbulence on feeding rate and gross-growth efficiency of three Acartia species (Copepoda: Calanoida) J Plankton Res 14:1085-1097

Savidge G (1981) Studies of the effects of small-scale turbulence on phytoplankton. J Mar Biol Assoc UK 61:477-488

Shimeta J, Jumars PA, Lessard EJ (1995) Influences of turbulence on suspension feeding by planktonic protozoa; experiments in laminar shear fields. Limnol Oceanogr 40 : $845-859$

Smith DC, Azam F (1992) A simple, economical method for

Editorial responsibility: Thomas Kiørboe (Contributing Editor), Charlottenlund, Denmark measuring bacterial protein synthesis rates in seawater using ${ }^{3} \mathrm{H}$-leucine Mar Microb Food Webs 6:107-114

Suttle CA, Chan AM, Taylor WD, Harrison PJ (1986) Grazing of planktonic diatoms by microflagellates. J Plankton Res 8:393-398

Thingstad TF, Hagström $\AA$, Rassoulzadegan F (1997) Accumulation of degradable DOC in surface waters: is it caused by a malfunctioning of the microbial loop? Limnol Oceanogr 42:398-404

Thingstad TF, Rassoulzadegan F (1995) Nutrient limitations microbial food webs, and 'biological C-pumps': suggested interactions in a P-limited Mediterranean. Mar Ecol Prog Ser 117:299-306

Thomas WH, Vernet M, Gibson CH (1995) Effects of smallscale turbulence on photosynthesis, pigmentation, cell division, and cell size in the marine dinoflagellate Gonyaulax polyedra (Dinophyceae). J Phycol 31:50-59

Thompson PA, Levasseur ME, Harrison PJ (1989) Light-limited growth on ammonium vs. nitrate: what is the advantage for marine phytoplankton? Limnol Oceanogr 34: $1014-1024$

Verity PG (1991) Feeding in planktonic protozoans: evidence for non-random acquisition of prey. J Protozool 38:69-76

Wheeler PA, Kirchman DL (1986) Utilization of inorganic and organic nitrogen by bacteria in marine systems. Limnol Oceanogr 31:998-1009

Yentsch CS, Menzel DW (1963) A method for the determination of phytoplankton chlorophyll and phaeophytin by fluorescence. Deep-Sea Res 10:221-231

Submitted: January 26, 1998; Accepted: July 10, 1998 Proofs received from author(s): October 2, 1998 